\title{
Antibacterial Activity of DMSO Extracts of Selected Plants Against Antibiotic Resistant Clinical Isolates
}

\author{
Ayşegül SARAL ${ }^{1 *} \mathbb{D}$, Uğur KARDİL ${ }^{2,3}$, Azer ÖZAD DÜZGÜN ${ }^{2,3}$ \\ ${ }^{1}$ Department of Nutrition and Dietetics, Faculty of Health Sciences, Artvin Coruh University, Artvin, Turkey \\ ${ }^{2}$ Department of Genetics and Bioengineering, Faculty of Engineering and Natural Sciences, Gumushane \\ University, Gümüşhane, Turkey \\ ${ }^{3}$ Medicinal Plants, Traditional Medicine Practice and Research Center, Gumushane University, Gumushane, \\ Turkey
}

Geliş / Received: 08/08/2018, Kabul / Accepted: 17/07/2019

\begin{abstract}
In this study, we aimed to find out new herbal materials that are able to inhibit the growth of the $P$. aeruginosa and E.coli clinical isolates that has antibiotic resistance. Clinical isolates used in this research are E. coli $(\mathrm{n}=1)$ and P.aeruginosa $(\mathrm{n}=1)$. Antibiotic susceptibility profiles of E. coli and P. aeruginosa were determined using e-test. Plants were collected in Trabzon region of Turkey are Calendula officinalis, Hypericum perforatum and Glycyrrhiza glabra. DMSO were used as solvent and solid-liquid extraction was employed. Micro-dilution method was preferred fo the determination of the minimum inhibitory concentration (MIC). MIC results were obtained through observation of turbidities. According to E-test results, while P. aeruginosa was resistant to piperacillin, piperacillin/tazobactam, meropenem and ceftazidime, E. coli was resistant to piperacillin, cefotaxime and ceftazidime. DMSO extract of Calendula officinalis showed very strong activity against PA1 with the best MIC ( $5 \mathrm{mg} / \mathrm{mL})$. DMSO extract of three plant had lower MIC values $(5-10 \mathrm{mg} / \mathrm{ml})$ for EC1 and PA1 than ampicillin. In future studies antibacterial activity of different solvents extracts of these plants and other plants against antibiotic resistant clinical isolates will be examined. Natural products from plants are promising in fighting with antibiotic-resistant bacteria.
\end{abstract}

Keywords: Antibiotic Resistance, Pseudomonas aeruginosa, Escherichia coli, Minimum Inhibitory Concentration, Plant Extract, E-test.

\section{Seçilen Bitkilerin DMSO Özütlerinin Antibiyotik Dirençli Klinik İzolatlara Karşı Antibakteriyel Aktivitesi}

\section{$\ddot{\mathbf{O z}}$}

Bu çalışmada, antibiyotik dirençli $P$. aeruginosa ve E.coli klinik izolatlarının büyümesini engelleyebilecek yeni bitkisel materyallerin keşfi amaçlanmıştır. Bu çalışmada kullanılan klinik izolatlar E. coli $(\mathrm{n}=1)$ ve P.aeruginosa'dır $(\mathrm{n}=1)$. E. coli ve $P$. aeruginosa'nın antibiyotik duyarlılık profilleri e-test kullanılarak belirlenmiştir. Trabzon yöresinden Calendula officinalis, Hypericum perforatum and Glycyrrhiza glabra bitkileri toplanmıştır. Çözücü olarak DMSO kullanılmış ve katı-sıvı ekstraksiyon yapılmıştır. Minimum inhibitör konsantrasyonunun (MİK) belirlenmesi için mikro dilüsyon yöntemi tercih edilmiştir. MİK sonuçları türbiditelerin gözlemlenmesiyle elde edilmiştir. E-test sonuçlarına göre, $P$. aeruginosa piperasilin, piperasilin/tazobaktam, meropenem ve seftazidime dirençli iken, E. coli piperasilin, sefotaksim ve seftazidime dirençliydi. Calendula officinalis'in DMSO özütü, en iyi MIC (5 mg / mL) ile PAl'e karşı çok güçlü aktivite göstermiştir. Üç bitkinin DMSO özütü, EC1 ve PA1 için ampisilin değerinden daha düşük MIC değerlerine (5$10 \mathrm{mg} / \mathrm{ml}$ ) sahip olduğu tespit edilmiştir. Gelecekteki çalışmalarda, bu bitkilerin ve diğer bitkilerin antibiyotik dirençli klinik izolatlara karşı farklı çözücülerle hazırlanan özütlerinin antibakteriyel aktiviteleri incelenecektir. Bitkilerden elde edilen doğal ürünler, antibiyotiğe dirençli bakterilerle savaşırken ümit vericidir.

Anahtar kelimeler: Antibiyotik direnci, Pseudomonas aeruginosa, Escherichia coli, Minimum İnhibisyon Konsantrasyonu, Bitki Özütü, E-test. 


\section{Introduction}

Escherichia coli (E.coli) is one of the most important pathogens in humans and is the most common cause of bloodstream infections and urinary tract infections (UTIs) among gram-negative bacteria (GNB) (Tavío et al., 2014; Vila et al., 2016). Cephalosporins and ceftazidime are effective treatment options for bloodstream infection (BSI) with $E$. coli due to their efficacy and low toxicity profiles (Hunter et al., 2010; Yuan et al., 2016).The emergence and spread of strains resistant to cefotaxime and ceftazidime among $E$. coli isolates have been frequently reported in recent years and in most cases these antibiotics have been developed resistance to these antibiotics due to CTX-M group $\beta$-lactamases (Tavío et al., 2014). In 2007, $12 \%$ of reported $E$. coli strains isolated from bacteraemia in England, Wales and Northern Ireland were found to be resistant to cefotaxime and/or ceftazidime (Hunter et al., 2010). CAESAR and EARS-Net datas indicated that resistance rate to the 3rd generation cephalosporins were $11.9 \%, 4.4 \%$ in Sweden, $38.1 \%$ in Bulgaria, $7.0 \%$ in Switzerland and $44 \%$ in Turkey among E. coli isolates (Akova, 2016). A broad spectrum of penicillin, piperacillin and an aminoglycoside antibiotic combination was frequently used in empirical treatment. However, BSIs that are caused by piperacillin-resistant E.coli isolates have been reported (Andersen et al., 2005).

Serious infections among hospitalized patients were caused by Pseudomonas aeruginosa frequently. Antibiotic treatment of this pathogen is extremely difficult because it has multiple resistance mechanisms, including $\beta$-lactamases, efflux pumps and a highly impermeable outer membrane (Lodise et al., 2007). Piperacillin-tazobactam is frequently used with its antipseudomonal activity (Kim et al., 2007).

According to the results of SENTRY (19972007), it was found that piperacillintazobactam is the most effective antipseudomonal drug in European and Latin American countries. In a study conducted in our country, it has been reported that piperacillin-tazobactam and amikacin are the most effective antibiotics against $P$. aeruginosa isolates. However, piperacillintazobactam resistance rates in $P$. aeruginosa isolates increased between 2007 and 2015 (Direkel et al., 2017).

Although carbapenems (eg, imipenem, meropenem, and doripenem) are the most important treatment options for severe infections caused by $P$. aeruginosa, carbapenem resistant isolates of $P$. aeruginosa are increasing worldwide (Mirsalehian et al., 2017; Rostami et al., 2018).

One of the major antimicrobials used to combat $P$. aeruginosa infections is ceftazidime (CAZ), a well-known cephalosporin. Horizontal acquisition of $\beta$ lactams or altered expression of $\mathrm{AmpC}$ results in the emergence of ceftazidime resistant isolates (Kos et al., 2016).

Increasing antibiotic resistance in bacteria has led to the emergence of new resistant phenotypes and the reduction of the effectiveness of antimicrobial compounds. In addition, the increasing in resistant bacteria makes the treatment of patients difficult, costly, and even impossible (Srivastava et al., 2014; Wikaningtyas and Sukandar, 2016). Many novel and safer therapeutic modalities are being explored to combat antibiotic resistance. Some of these are bacteriophages, virophages, monoclonal antibodies, nanomedicines, probiotics, antioxidants, 
fruits and vegetables and herbal remedies. Out of all these alternative and therapies, ayurvedic/herbal therapies are gaining much momentum (Dhama et al., 2014).

The present study aimed to evaluate antimicrobial effects of three selected plants (Calendula officinalis, Glycyrrhiza glabra, Hypericum perforatum) against, antibiotic resistant E. coli and P.aeruginosa isolates.

\section{Material and Methods}

\subsection{Bacterial Strains}

Previously, P. aeruginosa $(n=1)$ and E.coli $(n=1)$ isolates were collected beetween January and Februrary 2018 and were screened for bla OXA-51, bla OXA-23, bla OXA-24, bla $a_{\mathrm{OXA}-58,}$ bla $a_{\mathrm{GES}}$, bla $a_{\mathrm{IMP}}$, bla $\mathrm{VIM}$, bla ${ }_{\mathrm{CTX}-\mathrm{M} 1}$, bla $a_{C T X-M 2}, b l a_{\mathrm{KPC}}$, bla $a_{\mathrm{NDM}-1}$ and Class 1 integron gene cassettes by PCR (not published data). Class 1 integron gene cassette and

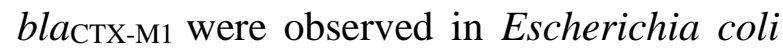
$(n=1)$ isolate.

\subsection{Antimicrobial Susceptibility Test}

P. aeruginosa $(n=1)$ and E.coli $(n=1)$ isolates were grown on MHB agar at $37^{\circ} \mathrm{C}$. Colonies of $P$. aeruginosa and E.coli were suspensed in MHB for turbidity of $0.5 \mathrm{McF}$ arland standard. These suspension were swabbed onto Mueller-Hinton Blood Agar plates. The E-test was performed using E-test strips containing piperacillin, piperacillin/tazobactam, meropenem, cefotaxime, ceftazidime according to the manufacturer's instructions in plates with $\mathrm{MH}$ agar. Plates were incubated at $37^{\circ} \mathrm{C}$ for $24 \mathrm{~h}$. The MICs were read according to the E-test reading guide. The results obtained with E-test were interpreted according EUCAST (Version 8.0).

\subsection{Plant materials and preparation of the DMSO extracts}

Dried leaves of Calendula officinalis, Glycyrrhiza glabra and Hypericum perforatum were collected from one haberdasher in Trabzon at March 2018. The dried leaves of the plants were crushed and powdered by a laboratory-type blender. Plant powders were stored at $40{ }^{\circ} \mathrm{C}$ to remove moisture. DMSO, being widely used as a universal solvent for natural products especially plant-derived products (Damasceno et al., 2015). DMSO (10\% of the final volume) was used as solvent in the extraction process. $5 \mathrm{~g}$ of the previously prepared dry powder plant samples were weighed and $50 \mathrm{~mL}$ of solvent was added onto the weighed plant samples. Plant samples were extracted for 2 hours at room temperature on a magnetic stirrer rotated at constant speed. The solutions obtained from extraction process were filtered through filter paper to remove solid particles. The resulting extracts were filtered through a $0.45 \mu \mathrm{M}$ porous syringe to be completely clarified. The clarified extracts were labeled and stored at 4 ${ }^{\circ} \mathrm{C}$ for future work.

\subsection{Determination of Minimum Inhibition Concentration}

The liquid microdilution method was used to determine the minimum inhibitory concentrations (MIC) of the crude extracts against antiobiotic resistant strains. Experiments were performed in triplicate using 96-well plates. Plant extracts were used at concentrations of $0.09-12 \mathrm{mg} / \mathrm{ml}$. Ampicillin used as a control at concentrations of $100-0.78125 \mathrm{mg} / \mathrm{ml}$ Pseudomonas aeruginosa and Escherichia coli isolates were grown on $\mathrm{MHB}$ at $37{ }^{\circ} \mathrm{C}$ until exponential phase. $50 \mu \mathrm{L}$ MHB added to each well except 
12th well. $100 \mu \mathrm{l}$ MHB was added to 12th well and this well used as a sterility control. Also, 11th well used as a growth control (\%10 DMSO). $50 \mu 1$ DMSO leaf extracts in concentration $20 \mathrm{mg} / \mathrm{ml}$ was added into first well and serial two fold dilution was performed up to 10th well; the final $50 \mu 1$ of the suspension discarded. Turbidity adjusted to $0.5 \mu \mathrm{l} \mathrm{McFarland} \mathrm{and} \mathrm{then} 50 \mu \mathrm{l}$ bacterial suspensions were added to $1-11$ th wells. Plates were incubated at $37^{\circ} \mathrm{C}$. The concentration of plant extract in the first well where growth was not observed was determined as MIC value.

\section{Resarch Findings}

Antimicrobial testing of E. coli (EC1) and $P$. aeruginosa (PA1) using E-test to screen for resistance to piperacillin, piperacillin /tazobactam, meropenem, cefotaxime, ceftazidime was conducted. E-test results for clinical isolates were shown in Table 1. According to these results, while PA1 was resistant to piperacillin, piperacillin/tazobactam, meropenem and ceftazidime, EC1 was resistant to piperacillin, cefotaxime and ceftazidime.

Table 1. E-test results for clinical isolates

\begin{tabular}{|l|c|c|c|c|}
\hline & \multicolumn{3}{|c|}{$\begin{array}{c}\text { Minimum Inhibition } \\
\text { Concetrations (MIC) }\end{array}$} \\
\hline Antibiotics & PA1 & & EC1 & \\
\hline PIP & $\begin{array}{c}>256 \\
\mu \mathrm{g} / \mathrm{ml}\end{array}$ & $\mathrm{R}$ & $\begin{array}{c}>256 \\
\mu \mathrm{g} / \mathrm{ml}\end{array}$ & $\mathrm{R}$ \\
\hline PTZ & $\begin{array}{c}24 \\
\mu \mathrm{g} / \mathrm{ml}\end{array}$ & $\mathrm{R}$ & 2 & $\mathrm{~S}$ \\
& $>256 / \mathrm{ml}$ & $\mathrm{R}$ & 0.64 & $\mathrm{~S}$ \\
\hline MRP & $\mu \mathrm{g} / \mathrm{ml}$ & & $\mu \mathrm{g} / \mathrm{ml}$ & \\
\hline
\end{tabular}

\begin{tabular}{|l|c|c|c|c|}
\hline CTX & - & - & $>256$ & $\mathrm{R}$ \\
$\mu \mathrm{g} / \mathrm{ml}$ & \\
\hline CAZ & $\begin{array}{c}128 \\
\mu \mathrm{g} / \mathrm{ml}\end{array}$ & $\mathrm{R}$ & $\begin{array}{c}>256 \\
\mu \mathrm{g} / \mathrm{ml}\end{array}$ & $\mathrm{R}$ \\
\hline \multicolumn{4}{|c|}{ Piperacillin, } \\
\hline
\end{tabular}

Piperacillin/Tazobactam, MRP: Meropenem, CTX: Cefotaxime, CAZ: Ceftazidime, R: Resistant, S: Sensitive

“_“ No breakpoints. Susceptibility testing is not recommended.

As a result of MIC experiments, it was determined that DMSO did not inhibit growth of tested microorganisms. Among the plant extracts tested, while DMSO extract of Calendula officinalis showed antibacterial activity against EC1 and PA1, DMSO extract of Glycyrrhiza glabra and Hypericum perforatum showed antibacterial activity against PA1 and $\mathrm{EC} 1$, respectively. MIC values of selected plants extracts were ranging from $5-10 \mathrm{mg} / \mathrm{mL}$ (Table 2). DMSO extract of Calendula officinalis showed very strong activity against PA1 with the best MIC (5 $\mathrm{mg} / \mathrm{mL}$ ). MIC values of Calendula officinalis and Hypericum perforatum for EC1 was 10 $\mathrm{mg} / \mathrm{ml}$. Also, MIC value of Glycyrrhiza glabra against PA1 was $10 \mathrm{mg} / \mathrm{ml}$. DMSO extract of three plant had lower MIC values $(5-10 \mathrm{mg} / \mathrm{ml})$ for $\mathrm{EC} 1$ and PA1 than ampicillin. 
Table 2. MIC Values of plant extracts and ampicillin against clinical isolates

\begin{tabular}{|l|l|l|}
\hline & \multicolumn{2}{|c|}{ MIC Values } \\
\hline Plant Extracts & EC1 & PA1 \\
\hline $\begin{array}{l}\text { Calendula } \\
\text { officinalis }\end{array}$ & $\begin{array}{l}10 \\
\mathrm{mg} / \mathrm{ml}\end{array}$ & $5 \mathrm{mg} / \mathrm{ml}$ \\
\hline Glycyrrhiza glabra & - & $10 \mathrm{mg} / \mathrm{ml}$ \\
\hline $\begin{array}{l}\text { Hypericum } \\
\text { perforatum }\end{array}$ & $\begin{array}{l}\mathrm{mg} / \mathrm{ml} \\
\text { Control }\end{array}$ & - \\
\hline Ampicillin & - & $\begin{array}{l}12,5 \\
\mathrm{mg} / \mathrm{ml}\end{array}$ \\
\hline
\end{tabular}

Antibiotic resistance is as old as the clinical use of antibiotics. Antibiotic-resistant pathogens have been reported shortly after the use of new antibiotics in hospitals. Almost all known bacterial pathogens developed over the years and up to daylight have developed resistance one or more antibiotic in clinical use (Cantas et al., 2013).

The increase in antibiotic resistance has led investigators to discover new antibiotics and plant extracts are important sources in this area. The antibacterial effects of plant extracts against bacteria have been studied for the last thirty years. In this period, many studies have been published evaluating the antimicrobial activity of Turkish plants. However, there is little information about the activity of plants against drug-resistant clinical isolates (Oskay et al., 2009).

Due to proven and important antibacterial effect of the compounds derived from plants, subject of this study is an investigation of antibacterial activity of DMSO extracts of Calendula officinalis, Glycyrrhiza glabra and Hypericum perforatum against drug-resistant E. coli and $P$. aeruginosa isolates.

E. coli and P. aeruginosa isolates were recovered from blood and sputum specimens, respectively. E-test was performed to determine antibiotic resistance profile of clinical isolates. According to E-test results, Class 1 integron and bla $a_{\mathrm{CTX}-\mathrm{M} 1}$ harboring isolate E. coli isolate (EC1) was resistant to piperacillin, cefotaxime and ceftazidime. $P$. aeruginosa (PA1) was resistant to piperacillin, piperacillin/tazobactam, meropenem and ceftazidime. Piperacillin, cefotaxime and ceftazidime resistant E.coli isolates and piperacillin/tazobactam, meropenem and ceftazidime resistant $P$. aeruginosa isolates have been reported in previos studies (Tavío et al., 2014; Hunter et al., 2010; Akova, 2016; Andersen et al., 2005; Direkel et al., 2017; Mirsalehian et al., 2017; Rostami et al., 2018; Kos et al., 2016). These isolates restricts treatment options and cause problems in clinical settings.

In one study, aqueous, acetone and methanol extracts of flower leaves of Calendula officinalis showed good antibacterial activity against Staphylococcus aureus, Bacillus cereus, E. coli, Klebsiella spp. and P.aeruginosa (Chandurkar et al.,, 2015). In another study, $C$. officinalis methanolic petal extract was reported to have great potential as an antimicrobial compound (with $53 \mathrm{mg} / \mathrm{ml}$ MIC value) against Klebsiella pneumoniae isolates co-producing ESBL and AmpC beta lactamases (Shah and Williamson, 2015). In our study, C. Officinalis DMSO extract MIC values of $10 \mathrm{mg} / \mathrm{mL}$ and $5 \mathrm{mg} / \mathrm{mL}$ were determined for EC1 and PA1, respectively. Similar to other studies, it can be concluded 
that $C$. officinalis has antibacterial activity against clinical isolates of antibiotic-resistant E. coli and P. aeruginosa.

Previous researchs have reported that Glycyrrhiza glabra is a precious medicinal plant due to its antimicrobial and antioxidant properties (Karahan et al., 2016). In a study conducted, it was determined that G. glabra root extracts showed significant antibacterial activities against Bacillus subtilis, Stapphylococcus aureus, E.coli and P.aeruginosa bacteria (Nitalikar et al., 2010). In another study, G. glabra's root methanol extracts were reported to exhibit good antibacterial activity against $E$. coli and $B$. subtilis, showing MIC values of 9.28 and 30.2 $\mathrm{mg} / \mathrm{mL}$, respectively (Abbas et al., 2015). Interestingly, in one study, it was reported that G. glabra's root methanol extracts does not inhibit growth of ESBL-producing $K$. pneumoniae and MIC values of 100 and 1000 $\mu \mathrm{g} / \mathrm{ml}$ against methicillin-resistant Staphylococcus aureus are present (Karahan et al., 2016). In the present study, the DMSO extract of G. glabra showed antibacterial activity only against the clinical isolate of $P$. aeruginosa (PA1). A MIC value of $10 \mathrm{mg} / \mathrm{ml}$ for PA1 may be considered as a good antibacterial activity.

Hypericum perforatum $L$. has various biological activities such as antidepressant, wound healing, antiinflammatory and antidiabetic. Studies in recent years has been directed towards revealing antimicrobial activity of this plants extracts against bacterial and fungal strains. In one study, the MIC values of the aqueous extract of Hypericum perforatum $L$. ranged from 8 to $32 \mu \mathrm{g} / \mathrm{ml}$ for S. mutans (ATCC21752), S. sobrinus (ATCC6715), L. plantarum (ATCC80141) and E. faecalis (ATCC29912) (Süntar et al., 2016). In another study, Hypericum perforatum aqueous extract was found to has antimicrobial activity against methicillinresistant Staphylococcus aureus (MIC values: 1.3 to $2.5 \mathrm{mg} / \mathrm{ml}$ ) (Reichling et al., 2001). In the present study, the DMSO extract of Hypericum perforatum showed antibacterial activity only against the clinical isolate of $E$. coli (EC1). A MIC value of $10 \mathrm{mg} / \mathrm{ml}$ for PA1 higher than found in other studies. These and similar differences in MIC values may be due to differences in physiological conditions of plants, environmental conditions, working parts of plants, extraction procedures, concentration of crude extracts and strains of test bacteria (Oskay et al., 2009).

\section{Conclusions}

Antibiotic resistance is a global public health problem. Antibiotic-resistant nosocomial and community-acquired isolates are increasing day by day. For this reason, researchers are trying to discover alternative methods or agents to fighting antibiotic resistance. The antibacterial activities of plants are versatile and depend on the concentration of phytocycles/phytochemicals, bioactive properties and synergistic and antagonistic effects at the same time. These phytochemicals are flavonoids, steroids, $\beta$-carotene, glycosides, coumarins, alkaloids, saponins, tannins, phenolic simple alkaloids, gallic acid and others (Dhama et al., 2014). In the present study, we have identified antibacterial activity of selected three plant aqueous extracts against antibiotic-resistant $E$. coli and $P$. aeruginosa isolates that cause difficulties clinical settings. We have also found that the MIC values of the three plant DMSO extractions are lower than the MIC value for ampicillin. We claimed that these extracts showed better antibacterial activity against tested isolates than ampicillin. 
Differences between MIC values in the literature and our results can be attributed to parameters such as strains of test bacteria and the extraction procedure. In future studies, we plan to investigate the growth inhibitory effect of these three plants extracted with different extraction methods on different clinical isolates.

\section{References}

Abbas, A., Zubair, M., Rasool, N., Rizwan, K. (2015). "Antimicrobial Potential of Glycyrrhiza glabra", Journal of Drug Design and Medicinal Chemistry, 1(2), 17-20.

Akova, M. (2016). "Epidemiology of antimicrobial resistance in bloodstream infections." Virulence, 7(3), 252-266.

Andersen, NF., Møller, J., Peterslund, NA. (2005). "Piperacillin-resistant Escherichia coli bacteraemia: Relation to empiric therapy and clinical outcome", Scandinavian Journal of Infectious Diseases, 37(2),90-95.

Cantas, L., Shah, SQ., Cavaco, LM., Manaia, CM., Walsh, F., Popowska, M., Garelick, H., Bürgmann, H., Sørum, H. (2013). “A brief multi-disciplinary review on antimicrobial resistance in medicine and its linkage to the global environmental microbiota", Frontiers in Microbiology, 14;4:96.

Chandurkar, P., Murab, T., Ahakey, N., Tripathi, N., Choudhary, A. (2015) "Antimicrobial activity of aqueous, acetone and methanol extracts of Calendulaofficinalis L. (Marigold) flower", International Journal of Pure \& Applied Bioscience, 3 (2), 386-388.

Damasceno, J., Giuberti, C., Gonçalves, R., Kitagawa, R. (2015) "Preformulation study and influence of DMSO and propylene glycol on the antioxidant action of isocoumarin paepalantine isolated from Paepalanthus bromelioides," Revista Brasileira de Farmacognosia, 25(4), 395-400.

Dhama, K., Tiwari R., Chakraborty S., Saminathan M., Kumar A., Karthik K., Wani MY., Amarpal, Singh SV. and Rahal A. (2014). "Evidence Based Antibacterial Potentials of Medicinal Plants and Herbs Countering Bacterial Pathogens Especially in the Era of Emerging Drug Resistance: An Integrated Update", International Journal of Pharmacology, 10, 1-43.

Direkel S, Uzunoglu E, Uzalp C, Findik E, Tontak S, et al. (2017). "Determination of Piperacillin/Tazobactam and Ticarcillin/Clavulanate Susceptibilities in Pseudomonas aeruginosa Isolates in Hospitalised Patients by E-test Gradient Method and Comparison of Results with Disk Diffusion Tests", Clinical Microbiology: Open Access, 6:273.

EUCAST. "The European Committee on Antimicrobial Susceptibility Testing. Breakpoint tables for interpretation of MICs and zone diameters. Version 8.1, 2018", http://www.eucast.org, 05.06.18.

Hunter, PA., Dawson, S., French, GL., Goossens, H., Hawkey, P.M., Kuijper, EJ., Nathwani, D., Taylor, DJ., Teale, CJ., Warren, RE., Wilcox, MH., Woodford, N., Wulf, MW., Piddock, LJ. (2010). "Antimicrobialresistant pathogens in animals and man: prescribing, practices and policies", Journal of Antimicrobial Chemotherapy, 65 (1), 3-17.

Karahan, F., Avsar, C., Ozyigit, II., Berber I. (2016). "Antimicrobial and antioxidant activities of medicinal plant Glycyrrhiza glabra var. glandulifera from different habitats", Biotechnology \& Biotechnological Equipment, 30 (4), 797-804. 
Kim, A., Sutherland, CA., Kuti, JL., Nicolau, DP. (2007). "Optimal dosing of piperacillintazobactam for the treatment of Pseudomonas aeruginosa infections: prolonged or continuous infusion?" Pharmacotherapy, 27(11),1490-1497.

Kos, VN., McLaughlin, RE., Gardner, HA. (2016). "Elucidation of Mechanisms of Ceftazidime Resistance among Clinical Isolates of Pseudomonas aeruginosa by Using Genomic Data", Antimicrobial Agents and Chemotherapy, 60(6), 3856-3861.

Lodise, TP., Jr, Lomaestro, B., Drusano, GL. (2007). "Piperacillin-Tazobactam for Pseudomonas aeruginosa Infection: Clinical Implications of an Extended-Infusion Dosing Strategy", Clinical Infectious Diseases, 44(3), 357-363.

Mirsalehian, A., Kalantar-Neyestanaki, D., Taherikalani, $\quad$ M., Jabalameli, F., Emaneini, M. (2017). "Determination of carbapenem resistance mechanism in clinical isolates of Pseudomonas aeruginosa isolated from burn patients, in Tehran, Iran", Journal of Epidemiology and Global Health, 7(3),155159.

Nitalikar, MM., Munde, KC., Dhore, BV., Shikalgar, SN. (2010). "Studies of Antibacterial Activities of Glycyrrhiza glabra Root Extract", International Journal of PharmTech Research, 2 (1), 899-901.

Oskay, M., Oskay, D., Kalyoncu, F. (2009). "Activity of Some Plant Extracts Against Multi-Drug Resistant Human Pathogens", Iranian Journal of Pharmaceutical Research, 8 (4), 293-300.

Reichling, J., Weseler, A., Saller, RA. 2001. "Current Review of the Antimicrobial
Activity of Hypericum perforatum L", Pharmacopsychiatry, 34 (1), 116-118.

Rostami, S., Farajzadeh Sheikh, A., Shoja, S., Farahani, A., Tabatabaiefar, MA., Jolodar, A., Sheikhi, R. (2018). "Investigating of four main carbapenem-resistance mechanisms in high-level carbapenem resistant Pseudomonas aeruginosa isolated from burn patients", Journal of the Chinese Medical Association, 81(2),127-132.

Shah Pratibha, J., Williamson Manita, T. (2015). "Antibacterial and Synergistic activity of Calendula officinalis Methanolic Petal Extract on Klebsiella pneumoniae Coproducing ESBL and AmpC Beta Lactamase", International Journal of Current Microbiology and Applied Sciences,4(4), 107117.

Srivastava, J., Chandra, H., Nautiyal, AR., Kalra, SJS. (2014). "Antimicrobial resistance (AMR) and plant-derived antimicrobials (PDAms) as an alternative drug line to control infections", 3 Biotech, 4(5), 451-460.

Süntar, I., Oyardı, O., Akkol, EK., Ozçelik, B. (2016). "Antimicrobial effect of the extracts from Hypericum perforatum against oral bacteria and biofilm formation", Pharmaceutical Biology, 54(6), 1065-1070.

Tavío, MM., Aquili, VD., Vila, J., Poveda, JB. (2014). "Resistance to ceftazidime in Escherichia coli associated with AcrR, MarR and PBP3 mutations and overexpression of sdiA", Journal of Medical Microbiology, 63(1),56-65.

Vila, J., Sáez-López, E., Johnson, JR., Römling, U., Dobrindt, U., Cantón, R., Giske, CG., Naas, T., Carattoli, A., MartínezMedina, M., Bosch, J., Retamar, P., Rodríguez-Baño, J., Baquero, F., Soto, SM. 
(2016). "Escherichia coli: an old friend with new tidings", FEMS Microbiology Reviews, 40(4),437-463.

Wikaningtyas, P., Sukandar, EY. (2016). "The antibacterial activity of selected plants towards resistant bacteria isolated from clinical specimens", Asian Pacific Journal of Tropical Biomedicine, 6 (1),16-19.

Yuan, XY., Yu, DY., Qu, XH., Xiao, XQ., Bi, B., Sun, SB., Chang, AY., Zhang, QB. (2016). "Increased resistance rate to ceftazidime among blood culture isolates of ESBL-producing Escherichia coli in a university-affiliated hospital of China", The Journal of Antibiotics (Tokyo), 69(3),169172. 